\title{
Smart-Specialization of The Agro-Industrial Complex in The Context of Digital Transformation of Regional Economic Systems
}

\author{
Anna M. Kulik', Elena A. Lavrinenko ${ }^{2 *}$, Julia V. Lyshchikova ${ }^{3}$, \\ Elena A. Stryabkova ${ }^{4}$ \\ 1,2,3,4Belgorod State University, Belgorod, Russia \\ E-mail: 'monakova@bsu.edu.ru, ${ }^{2}$ agm.ird@yahoo.com, ${ }^{3}$ julia@gmail.com, ${ }^{4}$ elena@gmail.com \\ ${ }^{*}$ Corresponding Author
}

JEL Classification:

$\mathrm{L} 52$

Q16

R11

Received: 07 June 2021

Revised: 17 July 2021

Accepted: 15 August 2021

\begin{abstract}
This article presents a domestic and foreign experience of "smart specialization" in agriculture in the digital economy. The method of calculating the indicators of digital maturity of the agro-industrial complex is considered. The forecast of indicators value of the agro-industrial digital maturity is presented until 2030. The article proposes a mechanism for adapting the smart specialization in agriculture. We consider it appropriate to introduce an online digital platform in agriculture, which allows creating conditions for interaction between sellers and buyers of regional agricultural machinery and related products. Based on the presented mechanism of adaptation of "smart specialization "in the field of agro-industrial complex, it should be noted that" smart specialization" is aimed at using the links that arise between the regions of economic activity. The priority areas of activity of the agro-industrial complex are presented.
\end{abstract}

\section{Keywords:}

smart specialization, agro-industrial complex; digital technologies; digital maturity

How to Cite:

Kulik, A. M., Lavrinenko, E. A., Lyshchikova, J. V., \& Strybkova, E. A. (2021). Smart-Specialization of The AgroIndustrial Complex in The Context of Digital Transformation of Regional Economic System. Etikonomi, 20(2), 309 - 318. https://doi.org/10.15408/etk.v20i2.22015. 


\section{Introduction}

Modern regional economic systems operate in conditions of global competitiveness. In the context of digital transformation, the foundation for achieving such competitiveness, including in the agro-industrial complex, can be intensifying interregional cooperation on the principles of "smart specialization." Developing "smart specialization" mechanisms in the agro-industrial complex requires research and improvement of the existing experience of implementing its principles, methods, and approaches in various countries. The activation of "smart specialization" can be a factor in the effective digital transformation of the agro-industrial complex of regional economic systems. The introduction of digital technologies provides a new stage in the development of the agro-industrial complex. Based on the use of advanced foreign experience, digital technologies are already introduced in the agro-industrial complex of many regions of the Russian Federation. However, the socalled "digital skills gap" between regions is constantly growing at the same time. At the same time, according to many experts, in the foreseeable future, it is the personnel with the necessary digital skills that will have competitive advantages in the labor market. Today, an acute shortage of such specialists acts as a powerful deterrent to the digitalization of the economy, including the agro-industrial complex. The preparation of students of an agricultural university is impossible without using practice-oriented training, the concept of smart technologies, ERP systems, e-learning, digital educational resources, and the participation of students in innovative projects.

The Smart Specialization Strategy is core to the economic development and growth policy. It is the central pillar of the Europe 2020 strategy and represents a profound structural revolution in developing regional innovation policy (OECD, 2013), which seeks to identify potential and real regional development priorities. "Smart specialization" arose from the idea that regions across the European Union have different economic and institutional structures that shape opportunities for their future development (Foray et al., 2011; Camagni \& Capello, 2013; Kroll, 2015). The goal of "smart specialization" is not to make the economic structure of the regions more specialized (that is, less diversified), but to use existing strengths, identify hidden opportunities, and create new platforms on which the regions can create competitive advantages in high-value-added activities.

Foray (2018) argues that "smart specialization" involves selecting and identifying new effective and efficient activities. There is a need to consider the heterogeneity of research models and technological specialization (Giannitsis \& Kager 2009). The development of the "smart specialization" strategy is the result of a "paradigm shift" in the development of the European Union's cohesion policy, from the predominantly redistributive logic typical of the last century's approach to the logic of development (Capello \& Cerisola, 2020). The previous logic was based mainly on the perceived need to compensate the lagging regions for the lack of particular prerequisites for growth, infrastructure, and access to education and health care (Fernandez, 2011). The new logic, driven by the general conditions for reducing public resources and achieving overall spatial efficiency and competitiveness, mainly advocates endogenous development, continuous innovation, and the prospect of growth (Foray, 2018). 
Zemtsov \& Barinova (2016) justified the need for a differentiated regional innovation policy in Russia based on "smart specialization" principles, which are aimed at preserving human capital and forming innovative entrepreneurship. The papers from Kutsenko et al. (2018) and Kutsenko et al. (2019) show that traditional regional innovation strategies in Russia meet most of the criteria for smart specialization. At the same time, in the absence of common rules for selecting, verifying, and synchronizing innovation development priorities, a common analytical database, organizational support tools, and expertise, even regions with high innovation potential find it challenging to form and implement unique strategies that fully comply with the principles of smart specialization. The formation of nonlinear network models of production and export diversification requires the formation of innovative clusters with "smart" specialization as local nodes of the GVC and the priority of improving the economic environment for continuous technology updates throughout improving the technologies themselves. The article by Kupriyanov (2019) considers the main aspects of using the concept of "smart specialization" in the activities of domestic and foreign companies, the influence of the cluster structure of the economy on the specialization of regions, the problems of forming regional economic strategies, the models of the innovation cycle, the model of the process of developing and implementing the strategy of innovative development of the region, the conditions of state support for the innovation system of Russia.

Currently, there are many difficulties in introducing "smart expertise" in agriculture and the digital evolution of the region's economic systems. In the light of the transition to the fourth industrial revolution, traditional systems of interaction and organization of production processes lose their former relevance and become uncompetitive. To increase competitiveness in the domestic and global markets, enterprises of various industries need to follow modern trends and modernize the production base and management system by introducing technologies based on artificial intelligence. Enterprises of the agricultural sector search and test various intelligent technologies get positive results from their application, which is reflected in profitability (Fedotova et al., 2019). Salnikov et al. (2018) analyze the technological system changes in the agro-industrial complex, the growth of the market volume of agricultural products in Russia due to the introduction of advanced information and technological solutions. The "road map" for developing the food market developed by the Agency for Strategic Initiatives is considered. Priority market segments are identified: "smart" agriculture, accelerated breeding, new sources of raw materials, affordable organic products, personalized nutrition.

This research aims to present a study of domestic and foreign experience of "smart specialization" in agriculture in the digital economy. The most popular areas in developing new information and communication technologies, automation, and robotics are noted: unmanned aerial vehicles, unmanned tractors and combines, the Internet of Things in agriculture, GIS technologies (remote sensing of the Earth), and distributed registries (blockchain). It is planned to integrate the technologies listed above for use in the management of agricultural enterprises in a single complex. It is noted that the data of 
the Russian federal state statistics service on the dynamics of agricultural development show successful attempts of the state authorities to digitize the agro-industrial sector. This action through the development of state programs and creation of an agricultural ecosystem; the comparative characteristic of small businesses and start-ups is given. Key difficulties in the development and implementation of start-ups in the agricultural sector of the economy are identified (Sheina \& Zavyalova., 2019).

\section{Methods}

This study is based on bibliographic, institutional, comparative methods of analysis, and the method of ranking and expert assessments. The object of the analysis is the concept of "smart specialization" in the agro-industrial complex, the experience of application in foreign countries, and the forms of development of "smart specialization" in Russia.

The following methods have been considered/applied to achieve the objectives: (a) Methodological approaches to development priorities; (b) Orders from the Ministry of Finance of the Russian Federation No. 600 of 11/18/2020 and No. 601 of 20.11.2020, which are quantitative indicators of digital transformation, the method of predicting the values of these indicators determine and predict the digital transformation of the people of the Russian Federation (Orders of the Ministry, 2020).

The article considers the method of calculating the "digital maturity" of the agroindustrial complex of the Russian Federation (1) (Orders of the Ministry, 2020). The percentage of achieving the target value of the number of ICT specialists in 2019 (base) - (1)100\%; 2030 (target) - 125\%. Percentage of achievement of the target value information technology expenditures in 2019 (base) - (1)100\%; 2030 (target) - 200\%. The share of achieving the target value of the maturity of the agro-industrial complex in 2019 (base) -0\%; 2030 (target) -125\%.

$$
\text { Digital Maturity }=0.25^{*}(\mathrm{ICT})+0.25^{*}(\mathrm{IT})+0.5^{*}(\mathrm{IDM}) \text {, }
$$

Where are ICT- share of specialists in information and communication technologies, \%; IT- share of the spending on information technology, \%; IDM- the index of maturity of the agro-industrial complex, \% (2).

$$
\mathrm{IDM}=(\mathrm{x} 1+\mathrm{x} 2+\ldots+\mathrm{x} 15) /(\mathrm{n})) * 100 \%
$$

$\mathrm{n}$ - number of indicators of the agro-industrial complex.

Table 1 shows the indicators for calculating the "digital maturity" of the agroindustrial complex (Orders of the Ministry, 2020). Using this method, we will determine the base value of the "digital maturity" indicator of the agro-industrial complex in 2019. Further, the dynamics of "digital maturity" values over the years, i.e., forecast, are formed by attracting expert knowledge. The source of statistical indicators used to assess the level of digital transformation of regions is the official publications of statistical bodies, the Ministry of Economic Development, the Ministry of Agriculture, and the Ministry of Digital Development, Communications, and Mass Media of the Russian Federation. 
Table 1. Indicators for calculating the "digital maturity" of the agro-industrial complex

\begin{tabular}{|c|c|c|}
\hline No & Indicator name & 2019 \\
\hline$x_{1}$ & $\begin{array}{l}\text { The share of agricultural producers with a digital profile that characterizes their economic } \\
\text { activities }\end{array}$ & 0.007 \\
\hline $\mathrm{X}_{2}$ & Percentage of farm animals with a digital profile & 0.003 \\
\hline$x_{3}$ & Percentage of breeding farm animals with a digital profile with data on genetic potential & 0.003 \\
\hline $\mathrm{X}_{4}$ & $\begin{array}{l}\text { The share of paperless transactions aimed at the sale of agricultural products, raw materials } \\
\text { and food }\end{array}$ & 0.024 \\
\hline $\mathrm{X}_{5}$ & $\begin{array}{l}\text { The share of agricultural producers that generate industry and financial and economic } \\
\text { reports automatically based on the data of accounting systems }\end{array}$ & 0.045 \\
\hline$X_{6}$ & $\begin{array}{l}\text { The share of agricultural producers with a digital profile that characterizes their economic } \\
\text { activities }\end{array}$ & 0.012 \\
\hline $\mathrm{X}_{7}$ & Percentage of agricultural machinery and equipment with a digital profile & 0.023 \\
\hline $\mathrm{X}_{8}$ & Percentage of agricultural land with a digital profile & 0.036 \\
\hline $\mathrm{X}_{9}$ & $\begin{array}{l}\text { The share of paperless transactions aimed at the sale of agricultural products, raw materials } \\
\text { and food }\end{array}$ & 0.039 \\
\hline$X_{10}$ & Share of arable land processed by unmanned tractors and self-propelled machines & 0.004 \\
\hline$X_{11}$ & $\begin{array}{l}\text { The share of agricultural producers that generate industry and financial and economic } \\
\text { reports automatically based on the data of accounting systems }\end{array}$ & 0.042 \\
\hline$x_{12}$ & $\begin{array}{l}\text { The share of agricultural producers with a digital profile that characterizes their economic } \\
\text { activities }\end{array}$ & 0.012 \\
\hline$X_{13}$ & $\begin{array}{l}\text { Percentage of vessels engaged in paperless document management within the framework } \\
\text { of catching aquatic biological resources }\end{array}$ & 0.018 \\
\hline$x_{14}$ & $\begin{array}{l}\text { The share of paperless transactions aimed at the sale of agricultural products, raw materials } \\
\text { and food }\end{array}$ & 0.006 \\
\hline$x_{15}$ & $\begin{array}{l}\text { The share of agricultural producers that generate industry and financial and economic } \\
\text { reports automatically based on the data of accounting systems }\end{array}$ & 0.015 \\
\hline
\end{tabular}

\section{Results and Discussion}

The practice of foreign experience in the field of "smart specialization" in the field of the agro-industrial complex made it possible to develop new directions of digital transformation and develop a conceptual apparatus of "digital maturity". The digital maturity of the agro-industrial complex shows the degree of readiness for the implementation of digital solutions in the agro-industrial complex (Orders of the Ministry, 2020). The methodology for calculating the "digital maturity" of the agro-industrial complex proposed by the Ministry of Digital Development, Communications and Mass Media of the Russian Federation makes it possible to identify not only the level of readiness for implementation, but also to prepare strategies for the digital transformation of regions (features of the digital transformation of the agro-industrial complex). They also include assessing the current level of digitalization, defining target prospects and key performance indicators, providing human resources, creating a digital transformation management system and financial models, as well as roadmaps. To form a forecast for the development of digitalization and the achievement of "digital maturity" of the agro- 
industrial complex, it is necessary to determine the basic value of "digital maturity". The authors of the article take 2019 as the base year. Using the formula (1), we calculate the index of maturity of the agro-industrial complex (see Table 1).

$$
\begin{aligned}
\mathrm{IDM}= & (0.007+0.003+0.003+0.024+0.045+0.012+0.023+0.036+0.039+ \\
& 0.004+0.042+0.012+0.018+0.006+0.015) /(15)) * 100 \%=1.9 \%
\end{aligned}
$$

Next, authors have calculated the "digital maturity" of the agro-industrial complex in the Russian Federation (2).

Digital Maturity (the agro-industrial complex) $=0.25^{*}(100)+0.25^{*}(100)+0.5^{*}(1.9)$ $=50.75 \%$

Figure 1. Forecast of The Value of The Agro-Industrial "Digital Maturity" Indicator until 2030

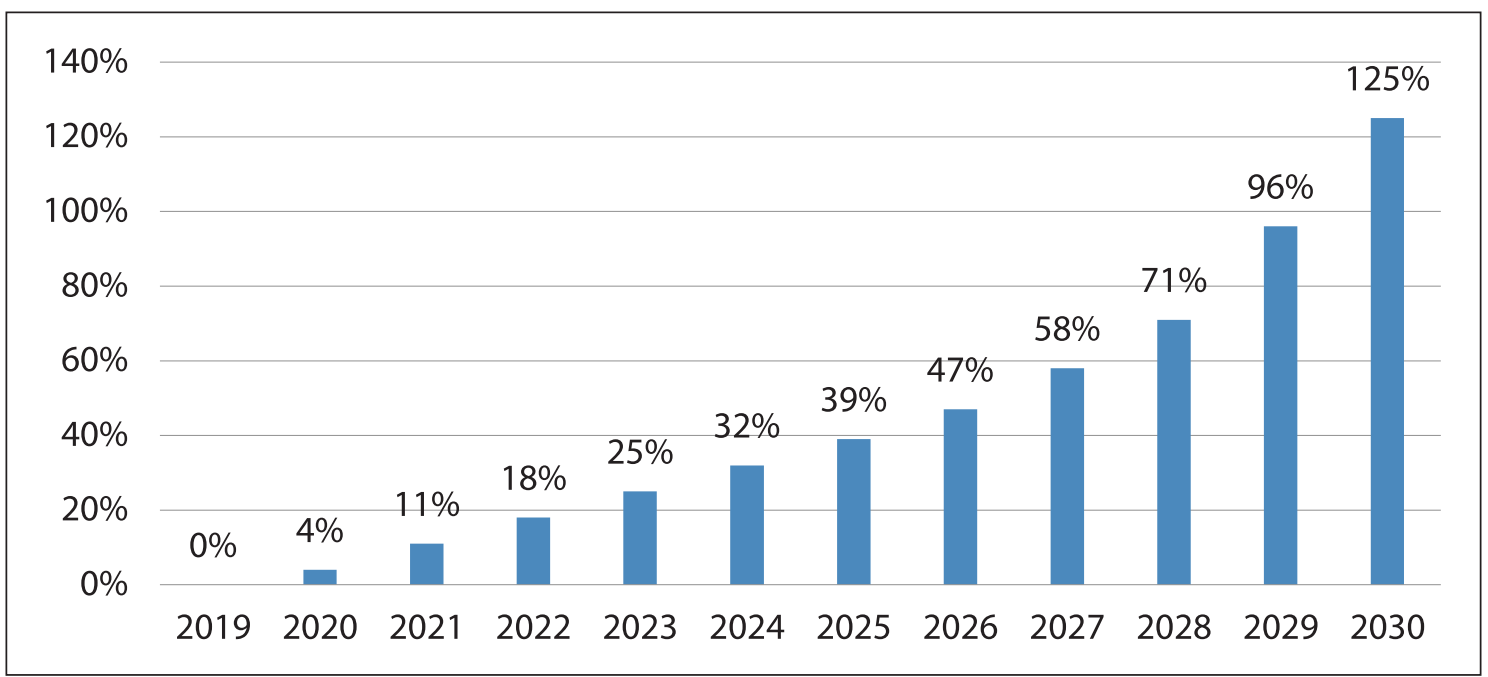

The "digital maturity" of the agro-industrial complex in the Russian Federation in 2019 is $50.75 \%$. This corresponds to the intensive pace of digitalization of the regions of the Russian Federation. We equate this value to $0 \%$ for the forecast assessment of "digital maturity" until 2030. Based on the data received, we will predict of the "digital maturity" of the agro-industrial complex of the regions of the Russian Federation (see Figure 1). The planned level of "digital maturity" of the agro-industrial complex in 2021 is $11 \%$ and is projected to reach $100 \%$ of the "digital maturity" of the agro-industrial complex by 2030 (See Figure 1).

To effectively implement the planned digital transformation strategy of the regions, a mechanism for implementing "smart expertise" in the field of agriculture has been proposed, which we call the "online digital platform in the field of agriculture", which allows for interaction between sellers and buyers of agricultural products Provides regional, related equipment and products. "Digital online platform in agriculture" acts as an effective online tool for agro-industry complexes with price collecting performance, CRM and ERP systems, business analysis, etc. It is also worth mentioning the benefits of this operating system in the difficult conditions that have arisen in the world in connection 
with the epidemic of COVID-19. The market allows you to trade any distance, which means it has another important option - it helps keep you healthy" (see Figure 2).

Figure 2. The Mechanism of Adaptation of "Smart Specialization" in The Field of Agro-Industrial Complex

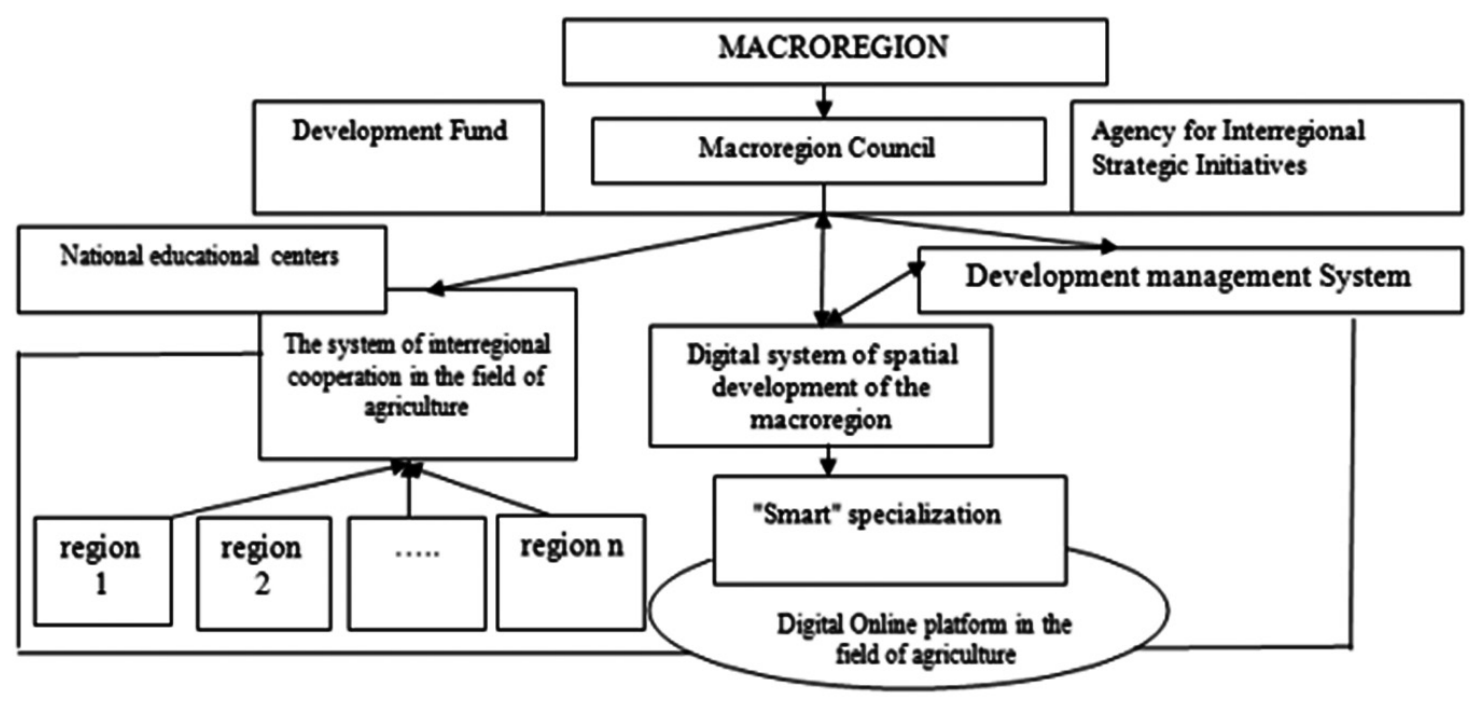

Based on the presented mechanism of adaptation of "smart specialization" in the field of agro-industrial complex, it should be noted that "smart specialization" is aimed at using the links that arise between the regions of economic activity. The agro-industrial complex is an element of the innovation ecosystem of the regions, while "smart specialization" is a much broader policy aimed at transforming the system itself. "Smart specialization", which includes an online platform in the field of agro-industrial complex, involves the inclusion of a development management system, interregional cooperation in the field of agro-industrial complex, a digital system of spatial development of the macro region, which will stimulate new areas of knowledge dissemination with a high degree of impact on economic growth in the context of digital transformation.

Thus, it is possible to consider the priority areas of activity of the agro-industrial complex of the Belgorod region in 2019 (see Table 2). Authors have found that livestock product (in particular, pig production and products of primary processing of livestock), as well as the production of cereals and legumes are the leaders in the production market of food products in the Belgorod region. Based on the above, we can conclude that the most significant innovations in the food sector of the agroindustrial complex of the Belgorod region should be in these industries. To implement the concept of "smart specialization", it is important to pursue a policy of holistic economic development and only in tactical terms it is advisable to allocate temporarily priority industries. The core of the region's "smart specialization" industries should sustainably reproduce itself on a new technological basis, constantly involving other industries in the orbit. 
Anna M. Kulik. Smart-Specialization of the Agro-Industrial Complex

Table 2. Priority areas of activity of the agro-industrial complex of the Belgorod region for 2019 Calculation based on (Russia in numbers, 2019)

\begin{tabular}{lcc}
\hline \multicolumn{1}{c}{ Industries, products } & Million rub & As \% of total \\
\hline Crop production, total & 19447 & 27.6 \\
Grains and seeds of cereals and legumes & 12050 & 17.1 \\
Soy Sunflower & 3748 & 5.3 \\
Seeds & 2326 & 3.3 \\
Open ground vegetables & 119 & 0.2 \\
Sugar beet root vegetables & 560 & 0.8 \\
Vegetable feed & 495 & 0.7 \\
Production of fruit and berry perennial plantings & 94 & 0.1 \\
Livestock products, total & 30459 & 43.3 \\
Live weight of pigs & 20301 & 28.8 \\
Live weight of poultry & 2288 & 3.3 \\
Raw cow's milk & 5067 & 7.2 \\
Eggs & 2918 & 4.1 \\
Commercial fish farming products & 93 & 0.1 \\
Production of primary processing of crop raw materials, total & 930 & 1.3 \\
Products of primary processing of livestock raw materials, total & 19029 \\
Industrial processing products, total & 506 & 27.0 \\
\hline Total & 70371 & 0.7 \\
\hline
\end{tabular}

\section{Conclusion}

A distinctive feature of the "smart specialization" strategy is its scalability, i.e., the possibility of using it outside the EU. This strategy has been implemented in Australia, Korea, South America, and other countries. It is necessary to pay attention to the characteristics of the institutional environment of regional development to use the "smart expertise" strategy in Russia. An essential component of strategies is the availability of an appropriate institutional framework, as "smart expertise" means a significant change in existing agro-industry policy and interaction principles between inter-regional development stakeholders. The concept of "smart specialization" is the combination of innovative and regional approaches. The concept must ensure the interaction between regional "smart specialization" in agriculture, considering regional economic systems and digital development processes. Since the Russian Federation is expected to achieve 100\% "digital maturity" of the agro-industrial complex by 2030, we have proposed a mechanism for adapting "smart expertise" in the field of agro-industrial complex in the process of digital transformation of regions. 


\section{Acknowledgment}

The study was carried out within the framework of an intra-university grant of the National Research University "BelSU" in accordance with Order No. 826-OD dated 14.08.2020, the theme of the project "Smart specialization in the agro-industrial complex of the region: digital transformation and convergent technologies".

\section{References}

Camagni, R., \& Capello, R. (2013). Regional Innovation Patterns and The EU Regional Policy Reform: Towards Smart Innovation Policies. Growth and Change, 44(2), 355-389. https://doi.org/10.1111/grow.12012.

Capello, R., \& Cerisola, S. (2020). Development Patterns and Their Sources of Competitiveness in the EUSALP Macro-Region. Regional Studies, 54(8), 1043-1056. https://doi.org/10.1080/ 00343404.2019.1652896.

Fedotova, G. V., Slozhenkina, M. I., Grigoryan, L. F., \& Kurazova, D. A. (2019). Intellectual Trends in The Development of Agriculture. Series: Economics. Sociology. Management, 9, 4(33), 84-95.

Fernandez, J. (2011). Why Location Matters: The Terms of a Debate. OECD Regional Outlook 2011: Building Relisient Regions for Stronger Economies. https://doi.org/ 10.1787/9789264120983-12-en.

Foray, D. (2018). Smart Specialization Strategies as a Case of Mission-Oriented Policy-a Case Study on The Emergence of New Policy Practices. Industrial and Corporate Change, 27(5), 817-832. https://doi.org/10.1093/icc/dty030.

Foray, D., David, P. A., \& Hall, B. H. (2011). Smart Specialisation from Academic Idea to Political Instrument, The Surprising Career of a Concept and The Difficulties Involved in Its Implementation. MTEI Working Paper 2011-001.

Foray, D., Goddard, J., Beldarrain, X. G., Landabaso, M., McCann, P., Morgan, K., ... \& Ortega-Argilés, R. (2012). Guide to research and innovation strategies for smart specialisation. Luxembourg: Publications Office of the European Union. doi, 10, 65746.

Giannitsis, T., \& Kager, M. (2009). Technology and Specialization: Dilemmas, Options and Risks. Knowledge Economists Policy Brief 8, 1-7.

Kroll, H. (2015). Efforts to Implement Smart Specialization in Practice-Leading Unlike Horses to The Water. European Planning Studies, 23(10), 2079-2098. https://doi. org/10.1080/09654313. 2014.1003036.

Kupriyanov, A. N. (2019). The Essence of The Concept of "Smart Specialization" in The Framework of Innovative Development of The Region. Economic and Humanitarian Sciences, 6 (329), 12-24.

Kutsenko, E., Islankina, E., \& Kindras, A. (2018). Smart by Oneself? An Analysis of Russian Regional Innovation Strategies Within the RIS3 Framework. Journal of the National Research University Higher School of Economics, 12(1), 25-45. 
Kutsenko, E. S., Abashkin, V. L., \& Islankina, E. A. (2019). Focusing Regional Industrial Policy via Sectorial Specialization. Voprosy ekonomiki, 5, 65-89.

OECD. (2013). Innovation Driven-Growth in Regions: The Role of Smart Specialisation. Organisation for Economic Growth and Development. Retrieved from: https://www. oecd.org/sti/inno/smart-specialisation.pdf .

Salnikov, S. G., Lichman, A. A., Tukhina, N. Yu. (2018). Technologies and Systems of Information Support in The Agro-Industrial Complex: Trends and Problems. Bulletin of the Moscow Humanitarian and Economic Institute, 3, 88-97.

Sheina, E. G., \& Zavyalova, M. Y. (2019). Digitization of The Agro-Industrial Complex of Russia as a Factor of Increasing The Investment Attractiveness of Innovative Start-ups. IOP Conference Series: Earth and Environmental Science, 315(2), 22-57.

Zemtsov, S. P., \& Barinova, V. A. (2016). Changing The Paradigm of Regional Innovation Policy in Russia: from Alignment to Smart Specialization. Voprosy ekonomiki, 10, 65-81. 